\title{
Application of the Requirements in Qiraat Mutawatirah as a Method in Determining the Validity of Data in Islamic-Based Research Methodology
}

Nur Sakiinah binti Ab Aziz, Mohamed Fathy Mohamed Abdelgelil, Mohd A'Tarahim bin Mohd Razali, Hussein Ali Abdullah al-Thulaia, Kasimah Kamaruddin

To Link this Article: http://dx.doi.org/10.6007/IJARBSS/v10-i12/8216

DOI:10.6007/IJARBSS/v10-i12/8216

Received: 11 September 2020, Revised: 14 October 2020, Accepted: 16 November 2020

Published Online: 29 November 2020

In-Text Citation: (Aziz et al., 2020)

To Cite this Article: Aziz, N. S. binti A., Abdelgelil, M. F. M., Razali, M. A. bin M., Al-Thulaia, H. A. A., \& Kamaruddin, K. (2020). Application of the Requirements in Qiraat Mutawatirah as a Method in Determining the Validity of Data in Islamic-Based Research Methodology. International Journal of Academic in Research Business and Social Sciences, 10(12), 59-68.

Copyright: (c) 2020 The Author(s)

Published by Human Resource Management Academic Research Society (www.hrmars.com) This article is published under the Creative Commons Attribution (CC BY 4.0) license. Anyone may reproduce, distribute, translate and create derivative works of this article (for both commercial and non-commercial purposes), subject to full attribution to the original publication and authors. The full terms of this license may be seen at: http://creativecommons.org/licences/by/4.0/legalcode

Vol. 10, No. 12, 2020, Pg. 59 - 68 


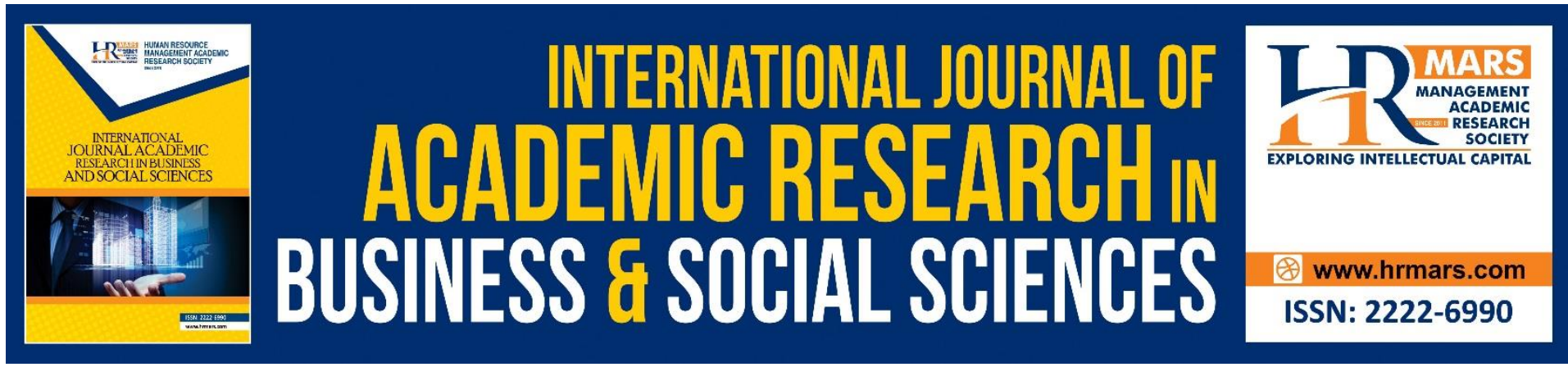

\title{
Application of the Requirements in Qiraat Mutawatirah as a Method in Determining the Validity of Data in Islamic-Based Research Methodology
}

\author{
Nur Sakiinah binti Ab Aziz, Mohamed Fathy Mohamed \\ Abdelgelil, Mohd A'Tarahim bin Mohd Razali, Hussein Ali \\ Abdullah al-Thulaia, Kasimah Kamaruddin \\ Faculty of Islamic Contemporary Studies, Universiti Sultan Zainal Abidin (UniSZA), 21300 \\ Kuala Terengganu, Terengganu.
}

\begin{abstract}
Qiraat mutawatirah is a qiraat (the style of reading) agreed by ulama (scholars) qiraat as sahih (valid) and is considered as a correct of reading al-Qur'an. Reading al-Qur'an by using qiraat mutawatirah is an ibadah (worship) and it will be rewarded. To ensure any qiraats is qiraat mutawatirah, scholars placed specific requirements to differentiates between valid qiraats with the questionable and made up qiraats. Scholars founds that the requirements stated can also be used to validate modern research in authenticate obtained data. This research focusing on two main objectives which are to identify the requirements for qiraat mutawatirah and to analyze the requirements to be used for validation in authenticating research data related to Islamic-based research methodology. What are the requirements for qiraat mutawatirah? Can the requirements still be used in the modern research context? To answer these questions, qualitative research method and content analyzing was used in this research. In conclusions, there are elements existed in the requirements such as sanad mutawatir, the number of narrator and the characteristic of the narrator can be used in validation of the research data and research about Islam.
\end{abstract}

Keywords: Qiraat, Mutawatir, Validity, Islamic Research Methodology

Introduction

Knowledge about qiraats is one of the important knowledges in Islamic traditional knowledge as well as other traditional knowledge such as Tawhid, Tafsir, Hadith, and Fiqh. Source of the qiraat is from the revelation given to the prophet Muhammad SAW (al-Habsy, 1996:26). Therefore, it is essential and important to know qiraats are mutawatir and their requirements to ensure the qiraats are mutawatir.

There are six classifications of qiraat according to the scholars. The classifications are, qiraat al-mutawatirah, qiraat al-masyhurat, qiraat al-ahadiat, qiraat al-syadhdhat, qiraat al- 
maudu'at, and qiraat al-mudrajat (al-Qattan, 1998:159-60, al-Suyutiy, t.t:77, al-Sabuniy, 1985:232). From those classifications, only two of them can be used in reciting al-Qur'an. The other four classification of qiraat are not recognize for their validity due to the lack of either sanad or do not meet the valid qiraat requirements (al-Qattan, 1998:159-60).

This paper focusing on the first type of qiraat, qiraat mutawarirah. Qiraat mutawatirah is the most authentic qiraat between the six classification of qiraat and it is a qiraat that is agreed upon by the scholars as close to the revelation to Rasulullah SAW (Manna' al-Qattan, 1998:159-60). Qiraat mutawatirah means qiraat or reciting brought by a group of narrators with a condition that the narrator may be impossible to carry out a fraud. The narration process prolonged until it reaches its end which is to the Prophet Rasulullah SAW (al-Suyutiy, t.t:79).

Moreover, the definition of mutawatir in IIm Qiraat (Qiraat Knowledge) is that a qiraat must be narrated by a just and dabit which then was taken from those who have similar characters as the narrator (Ibn-Jazariy, 2014:54). This occurs continuously from last narrator to the first narrator taking the narration. A narrator is a person who is fair ('adalat). According to the Hadith Scholars, a narrator must be Muslim, sane, mature, respected, knowledgeable, dignified, and someone who avoid engaging in matters that violate religious teaching. A narrator also cannot be involved in any act of kufr, shirk, bid'ah, ftraaasiq and the like. A narrator also rarely commits small sins which do not affect his adalat (Ahmed, 2000:72). On the other hand, the meaning of dabit is a narrator known to the qiraat scholars as a person who are less making offences or rarely making mistakes in narrating a qiraat (Ibn-Jazariy, 2014:54).

The inspection done on the definition of qiraat mutawatirah and mutawatir shows there are several characteristic to be found for qiraat mutawatirah. Therefore, these two definitions need to be identified and analyzed to know the suitability for the current research method especially in validating data. Apart from the definition, the conditions of qiraat mutawatirah must also be identified. There arise several questions from here, what are the conditions of qiraat mutawatirah and does these conditions suitable to be used in as a method to determine the validity of research data.

These two questions are summarized in two main objectives of this paper which are to identify the conditions of qiraat mutawatirah and to analyze these requirements for applications in validating the data in Islamic research. This paper conducting a qualitative study using document analysis method and content analysis to achieve these objectives.

Generally, the result from analysis in this paper show that there are four main sections to this approach. Firstly, to clarify the requirements of qiraat mutawatirah through history; Secondly, obtaining mutawatir concept from the requirements of the qiraat mutawatirah; Thirdly, describing the method of determining the validation of data in Islamic research; and lastly, the conclusion.

\section{Requirements of Qiraat Mutawatirah}

IIm Qiraat is one of the oldest knowledges in Islamic history starting from the Rasulullah SAW era alongside the revelation of al-Quran to the Prophet SAW. This knowledge is growing along 
with the development of Islam to the outside of Arabs (al-Zarqaniy, 2001:312-313; 'Abbas, 2007:124, al-Ibrahim, 1996:52). However, after several years passes and many have taken this qiraat from the companions of Rasullullah r.a, there are bound to have disagreement and dissention among them. Thus, the Caliph 'Uthman bin 'Affan r.a has instructed to collect alQuran in one mashaf (book) and other copies besides those collected were burned (Zanjalah, 2001:9-11).

Consequently, qiraat scholars who are aware of this situation begun to examine and screen back each qiraat obtained. According to the scholars, the first person to study and create requirements for determining qiraat mutawatirah is Imam Ibn Mujahid (al-'Abidiy, 2006:151 \& 2009:31). He studied by looking at some of the criteria and characters that a qari need to meet. Once the study completed, several requirements have been determined. The requirements are that a qiraat shall comply one of the Rasm 'Uthmany even in assuming, fulfilling one of the Arabic grammars even with one form only, and the sanad of the qiraat shall be mutawatir (al-Habsy 1996: 30; al-Syanqitiy 2000: 86). To further clarify the requirements, refer to the following Figure 1.

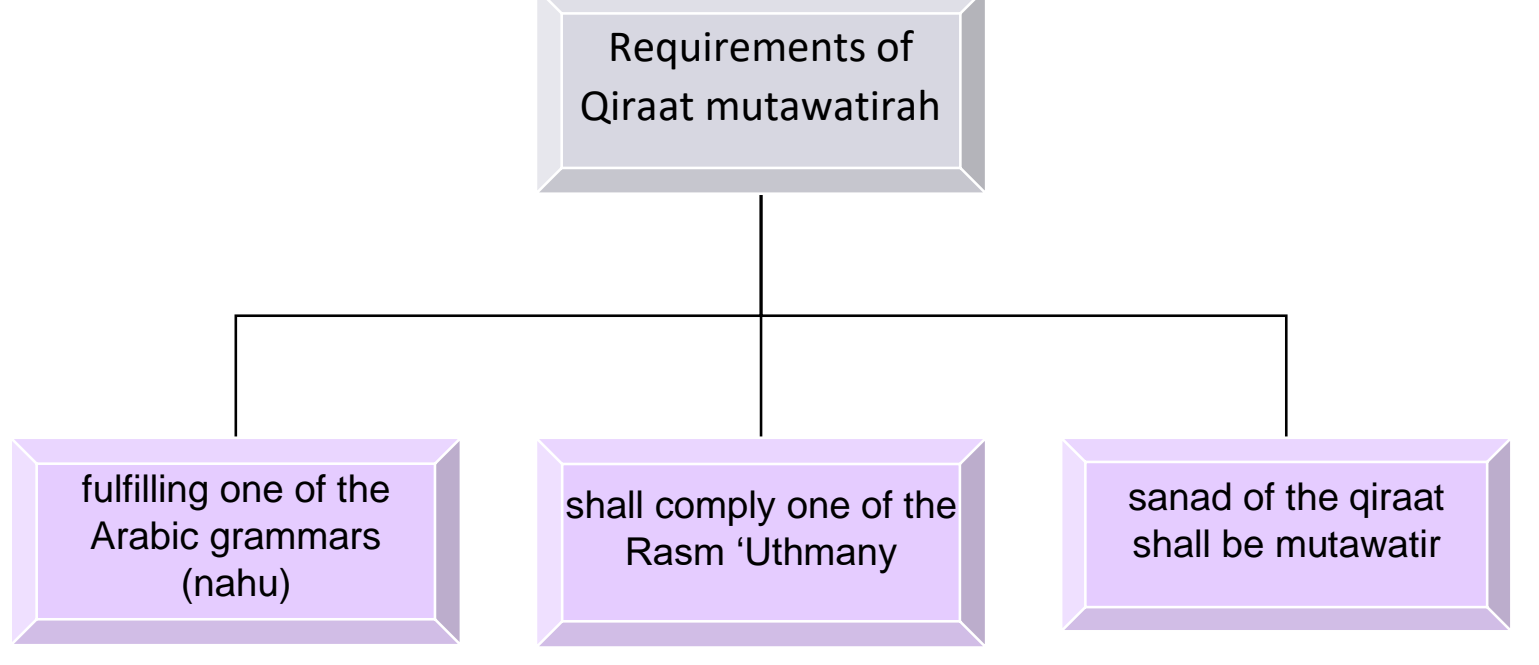

Rajah 1: Requirements of Qiraat Mutawatirah

Based on the three requirements of the qiraat mutawatirah, it is found that, in order one of the qiraat to be determined as sahih (authentic), it need to pass these three requirements during the screening. If one of those requirements is not fulfilled, a qiraat does not count as qiraat mutawatirah. The qiraat will belong to one of the five other types of qiraat.

\section{Analysis of The Requirements of Qiraat Mutawatirah and Mutawatir Concept}

The study of these three requirements need to be done to produce a suitable concept suitable in current research methods. First requirement, the qiraat must meet Arabic grammar even with wajh (form) either it is agreed on the wajh or there is khilaf that does not affect its meaning. Qiraat scholars do not look at the most widely used in Arabs, but they look to the most found in the narration and collection of the said grammar (al-Zarqaniy, 2001:499). This is because the Knowledge of Qiraat is a sunnah that is followed, which is based on the sanad and not merely the opinions or logic of common sense (al-Qattan, 1998:158). 
The second requirement is the qiraat shall comply one of the rasm 'uthmaniy even in assumption ${ }^{1}$. Fulfilling one of the rasm 'uthmaniy means that the qiraat shall comply one of the qiraats found in the mashaf rasm 'uthmaniy. This was stated because when the companions wrote mashaf rasm 'uthmaniy, they strive in fulfilling the qiraat language they knew ('Abbas, 2007:257).

The third requirement is that the qiraat shall have a sanad which is mutawatir. It is due to the qiraat is a sunnah which is followed based on the strength of the safe transfer (salamat alnaql) and on the sahih narration (al-Qattan, 1998:158).

Sanad mutawatir means a narrator who narrated a qiraat must be fair and dabit (strong memory). Every narrator must have similar characteristic from the last narrator to the first narrator. In addition, the qiraat should be popular among qiraat scholars, there are not many mistakes in the qiraat and it is not unfamiliar qiraat to the scholars (al-Suyutiy, t.t:78). Mutawatir or al-tawatur specifically means a group of narrators from one generation which from them was impossible for them to fabricate and have narrated qiraats from a group of narrators from previous generation. This process passed through from the last narrator to Rasulullah SAW, the first narrator (Syalabiy, 1999:19) through al-Sama' and al-Musyafahah methods (al-'Abidiy, 2006:154; Sulaiman, 2013:76).

Moreover, from the definition of mutawatir itself, the importance of the number of people in mutawatir is also important. If the number in a group delivering news was insufficient to produce a sahih information, then it does not consider to be mutawatir.

In this research on the method to determine the validity of the data using the requirements of qiraat mutawatirah, it only focusing on sanad mutawatir. This is because sanad mutawatir can be used as one of the methods in current research, while there are no similar points in the current research methods for the other two requirements. Therefore, those two requirements are categorized as the requirements only for IIm Qiraat. Thus, they will not be discussed in this study and only focusing on the requirements of sanad mutawatir only.

Scholars forms an opinion that a concept can be formed to create a core in Islamic research methods during researching the content of qiraat mutawatirah and its requirements which is sanad mutawatir. The concept was named as the mutawatir concept in conjunction with the important of mutawatir in determining the validity of qiraats in $1 / \mathrm{m}$ Qiraat. Figure 2 below described this concept further.

\footnotetext{
${ }^{1}$ What is meant by assumptions is that such recitation of "maliki yawmi al-din" in Surah al-Fatihah, the lafz of 'maliki' written in all mashaf al-Qur'an without harf alif. Then if reading 'malik' which is short, it fulfilled the rasm, while if reading 'maliki' with the length of two harakat, then it fulfilled the assumption (Manna' al-Qattan, 1998:158).
} 


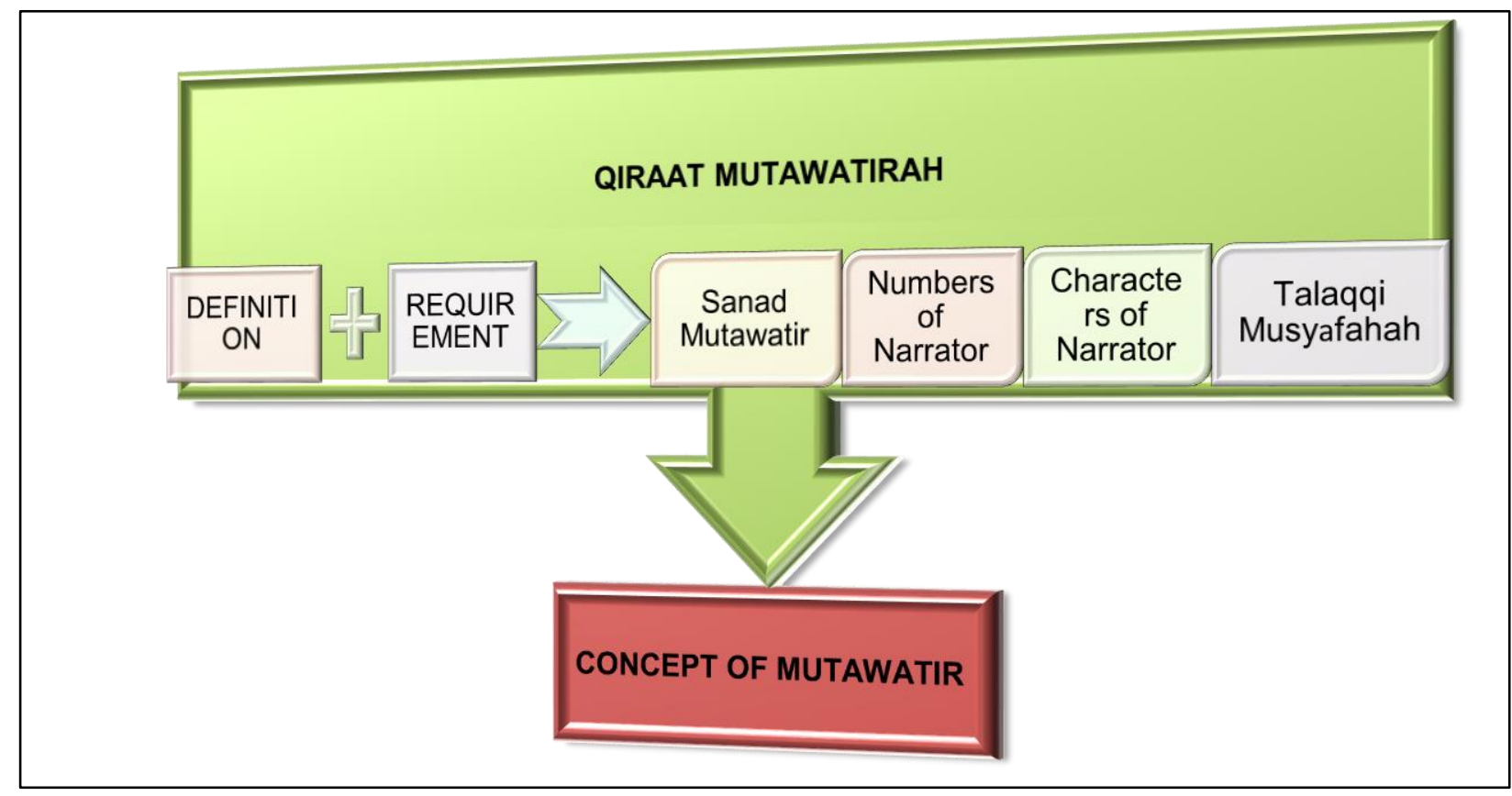

Figure 2: The Construction of Mutawatir Concept

From the figure above, this concept was constructed based on the definitions and the requirements of qiraat mutawatirah. Research into both points needs to be done because the construction of the mutawatir concept needs to be in-depth and screened in every intends either on surface or implied. Based on the definitions and its requirements, researchers may review its suitability for its applications in determining the data validity in Islamic research. More detailed information will be described in details on next sub-topics.

\section{The Construction of Islamic Research Data Determination Method based on the Requirements of Qiraat Mutawatirah}

Before explaining the method of determining the validity of Islamic research-related data, the method of determining the validity of common research data should be briefly explained first. The common research methods mentioned here are research methods adopted by all researchers in all academic fields. The methods were inspired from Western thought and was formed based on their worldview (Salleh, 2010:135-136)

There are various sections in research methods. Among these sections include qualitative studies, quantitative studies, field studies, data collection methods, data validity methods and there are many more methods in academic research. However, this paper focusing on methods of validating data as well as ways on validating a set of data. The methods of validating data in common research is one of the important aspects to ensure the validity of the data and the research itself. Therefore, there are several methods in common research to determine the validity of data.

According to the common research method, to validate a research data, the researcher must carefully examine the information obtained to produce a conclusion based on solid evidence. The researchers need to collect a large amount of data and explain the data and documents on how they collect and examine the said data. In addition, they also need to identify various processes, sources, or mechanisms in the collected data. Then they also need to look for 
patterns on similarity and differences, similar and differs aspect from it. The researchers responsible in arranging various explanation and discussion, finding a more authentic, legitimate, correct, or worthy among them to be tested whether the study is conducted fairly or not (Neuman, 2007: 328; Wainer \& Braun, 1988:xvii, Ismail, 2015:84).

There are several types of methods used in common research for measuring and validating a set of data. The methods are construct validation, criteria validation, practical validation, content validation, internal and external validation, ecology validation, statistic validation, surface validation and simultaneous validation (Wainer \& Braun, 1988:51-56; Weller \& Romney, 1990:79-82; Ismail, 2015:85-88; Neuman, 2007:118-119). Moreover, among other methods in validating the data are cumulative validation, communicative validation, argumentative validation, triangulation, and respondent validation (Bapir, 2010:10).

Even though there are many existing validation methods for data validation in mainstream research, there are also specific validation methods in Islam to determine the validation of data. In Islam, Islamic-related research methods were especially built on the main pillar of Islam which are al-Qur'an and al-Sunnah. Both al-Qur'an and al-Sunnah are the most important key in the formation of Islamic knowledge such as IIm Hadith, IIm Usul Fiqh, and IIm Qiraat.

Based on the concept of mutawatir in IIm Qiraat, elements extracted from it are found to be able to form powerful and reassuring tools in determination of validity of data. This study will be focusing on four main points from the concept which are sanad mutawatir, number of narrators, character of narrator, and talaqqi musyafahah methods.

Sanad mutawatir is a sanad that is constantly connected from narrator to narrator until it reaches the first narrator. The sanad that is connected in every tabaqat (stratum or generation) is very important in determining the authenticity of a qiraat. If one of those tabaqat detached due to certain reasons, then the qiraat cannot be considered as a qiraat mutawatir. If this first point is applied in the context of research data validity, to obtain a legitimate data, researchers needs to know from where and from whom they got the said data. If the researcher is able to track the data to the first source, then the data obtained are strong and definite.

The number of narrators is important to make a sanad mutawatir. The number of narrators on every tabaqat or generation should be sufficient until it is irrefutable which the data cannot be falsified. However, there are no fix number on how many narrators needed to be sanad mutawatir. This was discussed by Ghazali (1950: 293-242), stating that scholars have consensus in the necessity in having a number of narrators to determine mutawatir of a sanad. However, there are dissension in determining the least number of narrators to produce tawatur (mutawatir). Some thought the least number of narrators needed to produce tawatur is five (5) people, other thought the number is twenty (20) people, forty (40) people, seventy (70) people, and some even stated that the least number needed is three hundred and thirteen based on the number of Muslim troops in the Badr Battle.

Second data validation method, the number of respondents was one of the benchmarks in in verifying the data. Thus, both fields have the similarity in this case. However, there are one 
obvious difference where concept of mutawatir did not only look at the sheer number, but also the character of the narrator (in this case respondents) itself.

A narrator should be famous with dabit character, which is strong memory, trustworthy, learning IIm Qiraat in a long period of time, as well as having students learning from the narrator and talaqqi with the narrator as scholars agreed. (Muhammad 'Ali al-Sabuniy, 1985:234). In addition to the characteristics mentioned, a narrator also needs to be fair, wise and Muslim (Ibn -azariy, 2014:54; al-Suyutiy, t.t:78; Salih, 1993:121; Vrettou, 2014). In Determining the validity of research data, the character of the researchers and respondents should also be considered. If they have good characteristics and moral, then the information obtained definitely a true information. This was explained in detailed in the character of narrator in IIm Qiraat. Thus, the implementation of the characteristic of narrator into this research method is a great step in maintaining the credibility and integrity of a researcher and respondent on the data.

Talaqqi musyafahah 2 method in $I I m$ Qiraat is to ensure that the qiraat is authentic is necessary in the study of narration of the qiraat. This is to confirm whether the narrator takes the qiraat by listening and reciting directly from the teacher or otherwise. The usage of narration qiraat by musyafahah is an important condition in IIm Qiraat because all qiraat was not evaluated unless using al-sama' and al-musyafahah (Ibn-Jazariy, t.t:49). Moreover, the narration of al-Qur'an and qiraat is the main knowledge as mashaf from the first decade of Hijrah did not have dots and line to read and only based on hearing alone (al-Zarqaniy, 2001:490). When a narrator recites inform of their teacher by listening directly from him, then the qiraat is considered as sahih and can be counted as one of the recitals of al-Qur'an. Besides that, there are also scholars who uses terms al-sama' and al-musyafahah, however, these terms have the same meanings to them.

Talaqqi musyafahah method is a method that is suitable to use when a researcher is in the process of collecting research data. In common research method, data taken from primary sources is a strong data. Therefore, talaqqi musyafahah requires researchers to find the related primary sources. If this method is used, the researcher undoubtedly gets strong data due to the primary sources.

\section{Conclusion}

In conclusion, it was found that the research method in Islam have existed in various discipline of Islamic Knowledge including $\mathrm{IIm}$ Qiraat. More specifically, the research on the requirements of qiraat mutawatirah found that there is a concept that can be applied in determining the validity of Islamic-related research data which is concept of mutawatir. Based on the elements found in this concept, a stronger method of determining the validity of Islamic-related research data can be constructed.

\section{References}

Syalabi, A. F. (1999). Al-Madkhal wa al-Tamhidi fi 'Ilm al-Qur'an wa al-Tajwid. Kaherah, Mesir: Maktabah Wahbah.

\footnotetext{
2 Talaqqi musyafahah means students are face directly with the teachers by observing the form of mouth, tongue and lips of the teacher during the pronunciation of the verses in the al-Qur'an (Ismail Masyhuri al-Hafiz, t.t.:31).
} 
Zanjalah, A. R. (2001). Hujjat al-Qiraat. Beirut, Lubnan: Muassasah al-Risalah.

Braun, H. W. H. I. (1988). Test Validity. Hillsdale, New Jersey: Lawrence Erlbaum Associates. Abbas, F. H. (2007). Muhadarat fi Ulum al-Qur'an. Jordan: Dar al-Nafais.

Al-'Abidiy, F. (2006). Al-Jam' bi al-Qiraat al-Mutawatirah. Beirut, Lubnan: Dar Ibn Hazm.

Al-'Abidiy, F. (2009). Kulliyyaat al-Tajwid wa al-Qiraat (Jam' wa Siyanah wa Syarh). Beirut, Lubnan: Dar Ibn Hazm.

Ibn-Jazariy. (2014). Al-Nasyr fi al-Qiraat al-'Asyr. Kaherah, Mesir: Maktabah al-Sofa.

Ibn-Jazariy. (n.d). Munjid al-Muqri'in wa Mursyid al-Talibin.

Al-Suyuti, J. (t.t). Al-Itqan fi Ulum al-Qur'an: Dar al-Fikr.

Lawrence, N. W. (2007). The basics of Social Research. Qualitative and Quantitative Approaches: Pearson Education.

Al-Qattan, M. (1998). Mabahith fu Ulum al-Qur'an. Beirut, Lubnan: Muassasah al-Risalah.

Bapir, M. A. (2010). Is it possible for qualitative research to be properly valid and reliable. The University of Warwick.

Al-Sabuni, M. A. (1985). Al-Tibyan fi 'Ulum al-Qur'an. Beirut, Lubnan: Alam al-Kutub.

Al-Habsy, M. (1996). Al-Qiraat al-Mutawatirah Wa Atharuha Fi Al-Lughah al-'Arabiyyah Wa al-Ahkam al-Syar'iyyah Wa al-Rasm al-Qurani. (Phd), Univerisit al-Quran al-Karim Wa al-'Ulum al-Islamiyyah, Sudan.

Al-Ghazali. (1980). Al-Mankhul Min Ta'liqat al-Usul. Damsyik: Dar al-Fikr.

Al-Zarqaniy, M. (2001). Manahil al-'Irfan fi 'Ulum al-Qur'an. t.t: Dar Qutaybah.

Mokhtar, W. K. A. W., Khairuldin, W. M. K. F. W., Ibrahim, A., \& Embong, A. H. (2018). Al'Aqīdat Al-Șahịhat as the Essential Element of Worldview of Development Integrity and Accountability. International Journal Of Academic Research In Business And Social Sciences, 8(11), 328-337.

Ridzuan, F. N. B., Mokhtar, W. K. A. W., Afifah, A., Amiruddin, R. E., \& Jamaludin, A. S. (2019). The Characteristic and Issues in Liberal Islam in Malaysia. International Journal Of Academic Research In Business And Social Sciences, 9(11).

Hamid, N. C., \& Mokhtar, W. K. A. W. (2019). The Comprehensive Aspect in Islam from Quran and Hadith Perspective. International Journal Of Academic Research In Business And Social Sciences, 9(11).

Azami, M. M. (1977). Studies in Hadith Methodology and Literature. Indiana: American Trust Publications.

Salleh, M. S. (2010). Kaedah Penyelidikan Berteraskan Islam: Keperluan, Kedudukan dan Hala Tuju. Paper presented at the Seminar Pengurusan Pembangunan Islam II: Kaedah Penyelidikan Berteraskan Islam, Universiti Sains Malaysia.

Al-Ibrahim, M. I. (1996). Buhuth Manhajiyyah fi 'Ulum al-Qur'an al-Karim. Amman, Jordan: Dar 'Ammar.

Ahmad, R. (2000). Introduction to al-Hadith. India: Adam Publishers \& Distributers.

Romney, S. C. W. A. K. (1990). Systematic Data Collection. Newbury Park, California: SAGE Publications, Inc.

Ismail, R. (2015). Metodologi Penyelidikan; Teori dan Praktis. Bangi, Selangor: Penerbit Universiti Kebangsaan Malaysia.

Al-Syanqitiy, M. M. (2000). Manjah Ibn al-Jazariy fi Kitabihi "al-Nasyr". (Ph.D), Imam Muhammad Ibn Saud al-Islamiyyah Universiti, Riyad.

Salih, S. (1993). ILMU HADITH Satu Pengenalan dan Kajian. Kuala Lumpur: Dewan Bahasa dan Pustaka. 
Sulaiman, S. (2013). Al-Qiraat Al-Mutawatirah dan Kesannya Terhadap Pentafsiran Al-Quran: Kajian terhadap kitab Marah Labid Li Kashf Ma'na Al-Quran Al-Majid karangan Nawawi Al-Bantani Tumpuan Terhadap Surah al-Baqarah. ((Unpublished Ph.D's Thesis)), Universiti Malaya.

Vrettou, A. (2014). The "Very Successful L2 Learner" In The Sixth Grade Of The Greek Elementary School As Portrayed Through A Qualitative Study. Multilingual Academic Journal Of Education And Social Sciences, 2(2), 1-15. 